\title{
Harmful Effects of Hyperoxia in Postcardiac Arrest, Sepsis, Traumatic Brain Injury, or Stroke: The Importance of Individualized Oxygen Therapy in Critically Ill Patients
}

\author{
Jean-Louis Vincent, ${ }^{1}$ Fabio Silvio Taccone, ${ }^{1}$ and Xinrong $\mathrm{He}^{2}$ \\ ${ }^{1}$ Department of Intensive Care, Erasme Hospital, Université Libre de Bruxelles, 1070 Brussels, Belgium \\ ${ }^{2}$ Department of Intensive Care, Sun Yat-sen University Cancer Center, Guangzhou 510060, China \\ Correspondence should be addressed to Jean-Louis Vincent; jlvincent@intensive.org
}

Received 13 November 2016; Accepted 27 December 2016; Published 26 January 2017

Academic Editor: Wan-Jie Gu

Copyright (C) 2017 Jean-Louis Vincent et al. This is an open access article distributed under the Creative Commons Attribution License, which permits unrestricted use, distribution, and reproduction in any medium, provided the original work is properly cited.

\begin{abstract}
The beneficial effects of oxygen are widely known, but the potentially harmful effects of high oxygenation concentrations in blood and tissues have been less widely discussed. Providing supplementary oxygen can increase oxygen delivery in hypoxaemic patients, thus supporting cell function and metabolism and limiting organ dysfunction, but, in patients who are not hypoxaemic, supplemental oxygen will increase oxygen concentrations into nonphysiological hyperoxaemic ranges and may be associated with harmful effects. Here, we discuss the potentially harmful effects of hyperoxaemia in various groups of critically ill patients, including postcardiac arrest, traumatic brain injury or stroke, and sepsis. In all these groups, there is evidence that hyperoxia can be harmful and that oxygen prescription should be individualized according to repeated assessment of ongoing oxygen requirements.
\end{abstract}

\section{Introduction}

Oxygen is the third most abundant element in the universe and essential for life, but it was only officially "discovered" in the early 1770 s separately by the British-born theologian, Joseph Priestly, and the Swedish apothecary, Carl Scheele $[1,2]$. It took another few years for its role in respiration to be identified by the French chemist, Antoine-Laurent Lavoisier, who also gave it its name $[1,2]$. Introduced into anaesthetic practice in the 1930s, oxygen is now one of the most widely used "drugs" in hospitalized patients. In a pointprevalence study conducted in 40 intensive care units (ICUs) in Australia and New Zealand in 2012, 59\% of patients were receiving mechanical ventilation; among those not receiving mechanical ventilation, $86 \%$ were receiving oxygen via nasal cannulas, facial masks, or noninvasive ventilation [3]. However, although oxygen therapy clearly has important benefits in many patients, we have become increasingly aware of the potential harmful effects of high oxygenation concentrations in blood and tissues (Figure 1). In a retrospective study comparing mortality rates and $\mathrm{PaO}_{2}$ levels in mechanically ventilated ICU patients, de Jonge et al. reported a U-shaped relationship with increased mortality rates at low and high $\mathrm{PaO}_{2}$ [4]. The potential risks of hyperoxia, with a focus on recent clinical evidence in specific groups of critically ill patients (Table 1), will be the emphasis of this short narrative review.

\section{Effects of Hyperoxia}

Adequate cellular oxygenation is essential for normal cell function, and a low $\mathrm{SaO}_{2}$ is life-threatening, especially in acute conditions. Providing supplementary oxygen will increase oxygen delivery in hypoxaemic patients, thus supporting cell function and metabolism and limiting organ dysfunction. However, in patients who are not hypoxaemic, supplemental oxygen will increase oxygen concentrations into hyperoxaemic ranges. Although human beings may be exposed to hypoxia, for example, when at altitude or as a result of pulmonary disease, we are never exposed to hyperoxia, 
TABLE 1: Some recent clinical studies on the risks of hyperoxia after cardiac arrest or myocardial infarction, in traumatic brain injury, stroke, sepsis, and mixed ICU patients.

\begin{tabular}{|c|c|c|c|}
\hline References & Study design & Hyperoxia measurements & Main finding \\
\hline \multicolumn{4}{|c|}{ After cardiac arrest or myocardial infarction } \\
\hline $\begin{array}{l}\text { Kilgannon et al. } \\
2010 \text { [11]. }\end{array}$ & $\begin{array}{c}\text { Retrospective cohort study, } 120 \\
\text { hospitals, } 6326 \text { patients (nontraumatic } \\
\text { cardiac arrest) }\end{array}$ & $\begin{array}{l}\text { First } \mathrm{PaO}_{2} \text { in the first } 24 \text { hours. } \\
\text { Hyperoxia: } \mathrm{PaO}_{2} \geq 300 \mathrm{mmHg}\end{array}$ & $\begin{array}{c}\text { Hyperoxia was associated with an } \\
\text { increased hospital mortality compared } \\
\text { with either hypoxia or normoxia (OR } \\
1.8[1.5-2.2])\end{array}$ \\
\hline $\begin{array}{l}\text { Bellomo et al. } \\
2011[23]\end{array}$ & $\begin{array}{l}\text { Retrospective cohort study, } 125 \text { ICUs, } \\
12108 \text { patients (nontraumatic cardiac } \\
\text { arrest) }\end{array}$ & $\begin{array}{c}\text { Worst } \mathrm{PaO}_{2} \text { in first } 24 \mathrm{~h} \text {. } \\
\text { Hyperoxia: } \mathrm{PaO}_{2} \geq 300 \mathrm{mmHg} \\
\text { Normoxia: } \mathrm{PaO}_{2} 60-300 \mathrm{mmHg}\end{array}$ & $\begin{array}{c}\text { Hyperoxia group had a higher hospital } \\
\text { mortality than normoxia (OR } 1.2 \\
[1.1-1.6])\end{array}$ \\
\hline $\begin{array}{l}\text { Kilgannon et al. } \\
2011[24]\end{array}$ & $\begin{array}{c}\text { Retrospective cohort study, } 120 \\
\text { hospitals, } 4459 \text { patients (nontraumatic } \\
\text { cardiac arrest) }\end{array}$ & Highest $\mathrm{PaO}_{2}$ in the first 24 hours & $\begin{array}{l}\text { A } 100 \text { mmHg increase in } \mathrm{PaO}_{2} \text { was } \\
\text { associated with a } 24 \% \text { increase in } \\
\text { mortality risk (OR } 1.24 \text { [1.18 to } 1.31])\end{array}$ \\
\hline $\begin{array}{l}\text { Ranchord et al. } \\
2012[25]\end{array}$ & $\begin{array}{l}\text { Pilot randomized controlled trial, } \\
\text { single-centre, } 136 \text { patients with STEMI }\end{array}$ & $\begin{array}{c}\text { Patients randomized to receive } \\
\text { high-concentration }(6 \mathrm{~L} / \mathrm{min} \text { ) or } \\
\text { titrated oxygen (to achieve oxygen } \\
\text { saturation } 93 \%-96 \% \text { ) for } 6 \text { hours after } \\
\text { presentation }\end{array}$ & $\begin{array}{l}\text { No differences in number of deaths in } \\
\text { the two groups (relative risk } 0.5,95 \% \\
\text { CI } 0.05-5.4, p=0.56 \text { ) }\end{array}$ \\
\hline
\end{tabular}

Janz et al. 2012 cohort study, single-centre 170 patients

[26] (cardiac arrest treated with mild therapeutic hypothermia)

Retrospective cohort study,

Lee et al. 2014 single-centre, 213 patients (cardiac

[27]

arrest treated with therapeutic hypothermia)

Stub et al. 2015

[14]

Prospective, randomized, controlled trial, 9 hospitals, 441 patients with STEMI
Highest $\mathrm{PaO}_{2}$ in first $24 \mathrm{~h}$.

Average $\mathrm{PaO}_{2}$ between ROSC and the end of rewarming.

Hyperoxia: $\mathrm{PaO}_{2}>157 \mathrm{mmHg}$ Normoxia: $\mathrm{PaO}_{2} 117-135 \mathrm{mmHg}$

Patients with an $\mathrm{SpO}_{2}>94 \%$ were randomized to receive $8 \mathrm{~L} / \mathrm{min}$ of oxygen or no supplemental oxygen from arrival of paramedics until transfer to the cardiac care unit

Increased hospital mortality for every $100 \mathrm{mmHg}$ increase in $\mathrm{PaO}_{2}$ (OR 1.49 $[1.03,2.14])$

$\mathrm{V}$-shaped association between $\mathrm{PaO}_{2}$
and poor neurologic outcome at
hospital discharge (OR 6.47 [1.68,
24.91])

An increased rate of recurrent myocardial infarction, an increase in the frequency of cardiac arrhythmias, and an increase in myocardial infarct size at 6 months on magnetic resonance imaging in the supplement group

Severe hyperoxia was associated with decreased survival (OR 0.83

[0.69-0.99] per hour exposure);

Retrospective analysis of a

Elmer et al. 2015

[12] single-centre, 184 patients postcardiac arrest
Mean hourly exposure in first $24 \mathrm{~h}$. Normoxia: $\mathrm{PaO}_{2}$ 60-100 mmHg; Moderate hyperoxia: $\mathrm{PaO}_{2}$ 101-299 mmHg;

Severe hyperoxia: $\mathrm{PaO}_{2} \geq 300 \mathrm{mmHg}$ moderate hyperoxia was not associated with survival but with improved SOFA score $24 \mathrm{~h}$ (OR 0.92 [0.87-0.98])

Conservative group had a shorter ICU length of stay; no difference in the proportion of survivors discharged from hospital with good neurological outcome compared to conventional

group

In traumatic brain injury (TBI) and stroke

Eastwood et al. Retrospective before-after nested 2016 [13] cohort study, single-centre, 50 patients postcardiac arrest
Conservative oxygenation: $\mathrm{SpO}_{2}$ $88-92 \%$

A $\mathrm{PaO}_{2}$ value of $110-487 \mathrm{mmHg}$ was considered optimal. Extreme hyperoxia had an independent association with decreased survival (OR $0.50[0.36,0.71]$ ) compared to

Davis et al. 2009 centres, 3420 moderate-to-severe [18]
Extreme hyperoxia: first $\mathrm{PaO}_{2}>$ $487 \mathrm{mmHg}$

$$
\text { patients }
$$
optimal range
Both low and high $\mathrm{PaO}_{2}$ had increased mortality.

Mean $\mathrm{PaO}_{2}$ in first $24 \mathrm{~h}$ hospital admission:

Brenner et al. Retrospective study, single-centre, 1547 2012 [19] severe TBI patients
Hyperoxia: $\mathrm{PaO}_{2}>200 \mathrm{mmHg}$ Normoxia: $\mathrm{PaO}_{2} 100-200 \mathrm{mmHg}$
Patients with hyperoxia had higher

hospital mortality (OR 1.50 [1.15-1.97]) and lower discharge GCS scores at discharge (OR 1.52 [1.18-1.96]) 
TABle 1: Continued.

\begin{tabular}{lc}
\hline References & Study design \\
\hline $\begin{array}{l}\text { Raj et al. 2013 } \\
{[20]}\end{array}$ & $\begin{array}{c}\text { Retrospective nested cohort analysis, } 5 \\
\text { hospitals, 1116 ventilated } \\
\text { moderate-to-severe TBI patients }\end{array}$
\end{tabular}

\begin{tabular}{lcc}
\hline $\begin{array}{l}\text { Rincon et al. } \\
2014[28]\end{array}$ & $\begin{array}{c}\text { Retrospective cohort, 84 ICUs, 2894 } \\
\text { stroke patients }\end{array}$ & $\begin{array}{c}\mathrm{PaO}_{2} \text { in the first 24 hours. } \\
\text { Hyperoxia: } \mathrm{PaO}_{2} \geq 300 \mathrm{mmHg} \\
\text { Normoxia: } \mathrm{PaO}_{2} 60-300 \mathrm{mmHg}\end{array}$ \\
\hline $\begin{array}{l}\text { Rincon et al. } \\
2014[29]\end{array}$ & $\begin{array}{c}\text { Retrospective cohort study, 61 } \\
\text { hospitals, 1212 ventilated TBI patients }\end{array}$ & $\begin{array}{c}\text { Hyperoxia: } \mathrm{PaO}_{2}>300 \mathrm{mmHg} \\
\text { Normoxia: } \mathrm{PaO}_{2} \text { 60-300 mmHg }\end{array}$ \\
\hline $\begin{array}{l}\text { Jeon et al. 2014 } \\
\text { [30] }\end{array}$ & $\begin{array}{c}\text { Prospective, observational cohort } \\
\text { database analysis, single-centre, 252 } \\
\text { patients (subarachnoid haemorrhage) }\end{array}$ & $\begin{array}{c}\mathrm{PaO}_{2} \text { AUC by observation time until } \\
\text { delayed cerebral ischemia (DCI). }\end{array}$ \\
$\begin{array}{c}\text { Hyperoxia: } \mathrm{PaO}_{2} \geq 173 \mathrm{mmHg} \text { (upper } \\
\text { quartile) }\end{array}$
\end{tabular}

$\begin{array}{cc}\text { Hyperoxia measurements } & \text { Main finding } \\ \text { Worst } \mathrm{PaO}_{2} \text { in first 24 h ICU } & \text { Hyperoxia had no independent } \\ \text { admission: } & \text { relationship with in-hospital mortality } \\ \text { Hyperoxia: } \mathrm{PaO}_{2}>100 \mathrm{mmHg} & (\text { OR } 0.94[0.65-1.36]) \text { and 6-month } \\ \text { Normoxia: } \mathrm{PaO}_{2} 75-100 \mathrm{mmHg} & \text { mortality (OR 0.88 [0.63-1.22]) }\end{array}$

myperoxia was independently

Hyperoxia was independently Hyperoxia was independently
associated with in-hospital mortality (OR 1.22 [1.04-1.48])

Hyperoxia was associated with a higher in-hosptial case fatality (OR 1.5 [1.02-2.4])

Hyperoxia group had a higher incidence of DCI (OR 3.16 [1.69 to 5.92]) and poor outcome (modified Rankin Scale 4-6 at 3 months after subarachnoid haemorrhage) (OR 2.30 [1.03 to 5.12]) Quintard et al. $\begin{aligned} & \text { Retrospective analysis of a database, } \\ & \text { single-centre, } 36 \text { severe TBI patients }\end{aligned}$
2015 [17]

Lang et al. 2016 [31]

Retrospective analysis using 2 databases, 432 ventilated patients (subarachnoid haemorrhage)
Hyperoxia: $\mathrm{PaO}_{2}>150 \mathrm{mmHg}$

Time-weighted average $\mathrm{PaO}_{2}$ during the first 24 hours

Low $\mathrm{PaO}_{2}<97.5 \mathrm{mmHg}$;

Intermediate $\mathrm{PaO}_{2}$ 97.5-150 mmHg; High $\mathrm{PaO}_{2}>150 \mathrm{mmHg}$
Hyperoxia was associated with increased cerebral microdialysis glutamate, indicating cerebral excitotoxicity

Patients with an unfavorable outcome had significantly higher $\mathrm{PaO}_{2}$, but high $\mathrm{PaO}_{2}$ has no effect on 3-month neurological outcomes (OR 1.09 [0.61-1.97]) or mortality (OR 0.73 [0.38-1.40])

\begin{tabular}{lc}
\hline $\begin{array}{l}\text { Stolmeijer et al. } \\
2014[32]\end{array}$ & $\begin{array}{c}\text { Prospective pilot study, 83 sepsis } \\
\text { patients in emergency department, } \\
\text { single-centre }\end{array}$ \\
\hline & \\
\hline & In Jonge et al. \\
2008 [4] & $\begin{array}{c}\text { Retrospective observational study, 50 } \\
\text { ICUs, 36307 ventilated patients }\end{array}$
\end{tabular}
2008 [4]

In sepsis

$\mathrm{PaO}_{2}$ after 5 min of a VentiMask $40 \%$ with $10 \mathrm{~L} \mathrm{O}_{2} / \mathrm{min}$. Hyperoxia: $\mathrm{PaO}_{2}>100 \mathrm{mmHg}$ In mixed ICU patients

Worst $\mathrm{PaO}_{2}$ in first $24 \mathrm{~h}$. Hyperoxia: $\mathrm{PaO}_{2} \geq 123 \mathrm{mmHg}$ (upper quintile) compared with $\mathrm{PaO}_{2}$ between 67 and $80 \mathrm{mmHg}$

Conservative oxygenation: $\mathrm{SpO}_{2}$ $88-92 \%$

Liberal oxygenation: $\mathrm{SpO}_{2} \geq 96 \%$

Panwar et al. Pilot randomized controlled trial, 4 2016 [33] ICUs, 103 patients

Girardis et al. Open-label randomized trial, 2016 [34] single-centre, 434 patients

Conservative oxygenation: $\mathrm{PaO}_{2}$

70-100 mmHg ( $\mathrm{SpO}_{2}$ 94-98\%)

Conventional oxygenation: $\mathrm{PaO}_{2}>$ $150 \mathrm{mmHg}\left(\mathrm{SpO}_{2} 97-100 \%\right)$

Helmerhorst et Observational cohort study, 3 ICUs, al. 2017 [35] 14441 ventilated patients

First $\mathrm{PaO}_{2}$ at ICU admission Mild hyperoxia: $\mathrm{PaO}_{2} 120-200 \mathrm{mmHg}$ Severe hyperoxia: $\mathrm{PaO}_{2}>200 \mathrm{mmHg}$
Of the hyperoxic patients, $8 \%$ died in hospital versus $6 \%$ with normoxia 


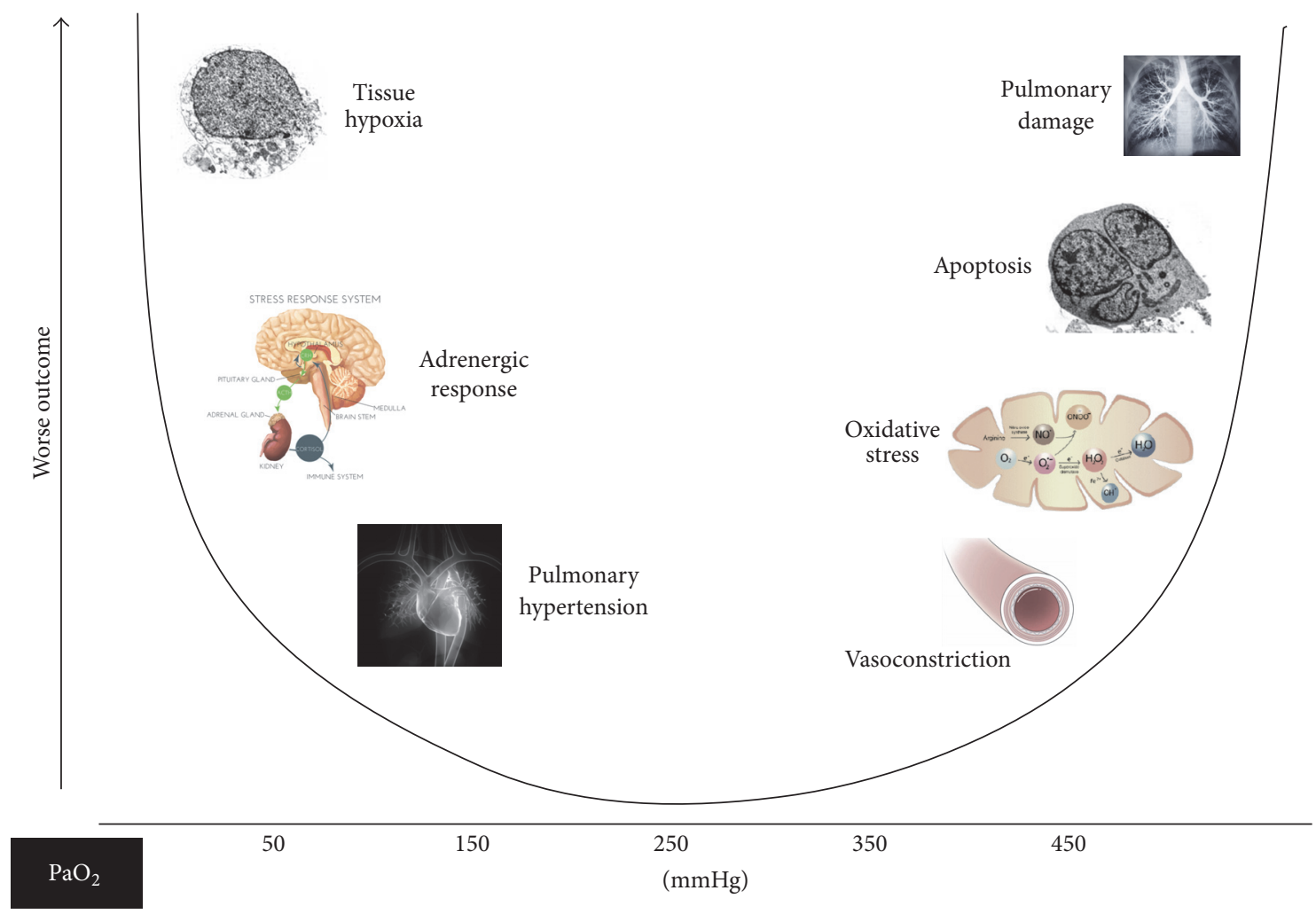

FIGURE 1: Schematic showing U-shaped association of $\mathrm{PaO}_{2}$ with outcome.

so that supplying extra oxygen to individuals who are not hypoxaemic is always a "nonphysiological" event.

Hyperoxia is associated with multiple effects in different organ systems. It can directly damage tissues via the production of reactive oxygen species (ROS) in excess of physiological antioxidant defence capabilities [5], leading to increased cell death by apoptosis and increased release of endogenous damage-associated molecular pattern molecules (DAMPs) that stimulate an inflammatory response, notably in the lungs [6] and vasoconstriction, likely as a result of reduced nitric oxide levels [7]. Orbegozo Cortés et al. recently reported that normobaric hyperoxia in healthy volunteers was associated with reduced capillary perfusion as assessed using sublingual side-stream dark field (SDF) video-microscopy [8]. It has been suggested that these vasoconstrictive effects may provide a means of protecting cells from the harmful effects of high $\mathrm{PaO}_{2}$ [9].

2.1. After Cardiac Arrest or Myocardial Infarction. Given the associated vasoconstriction and increased ROS release, hyperoxia may be particularly harmful after cardiac arrest [10]. Experimental and observational data have given conflicting results regarding the effects of hyperoxia in this setting [10]. In a retrospective analysis of data from 6326 postcardiac arrest patients admitted to ICUs in 120 US hospitals between 2001 and 2005, patients with hyperoxia (defined as $\mathrm{PaO}_{2}$ of $\geq 300 \mathrm{mmHg}$ ) on arrival in the ICU had higher mortality rates than those with normoxia or hypoxia; in multivariable analysis, hyperoxia exposure was an independent predictor of in-hospital death (odds ratio 1.8 [95\% CI 1.5-2.2], $p<0.001$ ) [11]. In an analysis of a registry database, severe hyperoxia (as identified by a $\mathrm{PaO}_{2}>$ $300 \mathrm{mmHg}$ ) was associated with increased mortality in postcardiac arrest patients, whereas moderate or "probable" hyperoxia $\left(\mathrm{PaO}_{2} 101-299 \mathrm{mmHg}\right)$ was not [12]. In a retrospective cohort study, patients managed according to a conservative oxygen approach after cardiac arrest, targeting an pulse oximetry oxygen saturation $\left(\mathrm{SpO}_{2}\right)$ of $88-92 \%$ had shorter lengths of ICU stay, although there were no differences in neurological outcomes [13]. In a multicentre trial conducted in 441 patients with ST-elevation myocardial infarction, patients with an $\mathrm{SpO}_{2}>94 \%$ were randomized to receive $8 \mathrm{~L} / \mathrm{min}$ of oxygen or no supplemental oxygen from arrival of paramedics until transfer to the cardiac care unit. Patients treated with oxygen had an increased rate of recurrent myocardial infarction, an increase in the frequency of cardiac arrhythmias, and an increase in myocardial infarct size at 6 months on magnetic resonance imaging [14]. These results do not support the use of routine supplemental oxygen after cardiac arrest or myocardial infarction. A randomized multicentre study is ongoing in Sweden aiming to randomize 6,600 patients with suspected acute myocardial infarction and $\mathrm{SpO}_{2} \geq 90 \%$ to either $6 \mathrm{~L} / \mathrm{min}$ of supplemental oxygen for 6 to 12 hours or room air [15].

2.2. In Traumatic Brain Injury and Stroke. Reduced cerebral oxygenation after brain injury is associated with impaired mitochondrial function and reduced metabolic rate and may 
be associated with an increased risk of secondary brain damage $[16,17]$. Treating such patients with hyperoxia may, therefore, be expected to have beneficial effects on outcomes. However, clinical studies have given conflicting results. In a retrospective study of more than 3000 patients with traumatic brain injury (TBI), hypoxaemia, and extreme hyperoxaemia $\left(\mathrm{PaO}_{2}>487 \mathrm{mmHg}\right)$ on admission were both asso-

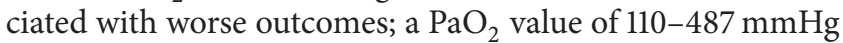
was considered optimal in this study [18]. Similar findings were reported by a more recent retrospective study in 1547 patients with TBI, with both low and high admission $\mathrm{PaO}_{2}$ levels independently associated with worse outcomes [19]. In a long-term outcomes study after TBI, although there was a significant association between hyperoxaemia and a decreased risk of 6-month mortality in univariate analysis, in multivariable analysis, hyperoxaemia was not independently associated with outcome [20]. In a small randomized trial, 68 patients with severe TBI received either $80 \%$ or $50 \%$ oxygen via mechanical ventilation in the first 6 hours after the TBI. Patients in the hyperoxia group had better outcomes at 6 months as assessed using the Glasgow Outcome Scale than patients in the normoxia group [21]. A planned larger study to compare treatment with an $\mathrm{FiO}_{2}$ of 0.4 or 0.7 in patients with TBI was terminated because of slow recruitment (NCT01201291). Interestingly, in a prospective study of 30 patients monitored with a brain tissue oxygen sensor, Vilalta et al. reported that a hyperoxia challenge was associated with improved cerebral metabolism only in patients with reduced metabolism at baseline [22].

Evidence from studies in patients with stroke is also conflicting. Lang et al. reported no effect on 3-month neurological outcomes or mortality of moderate hyperoxaemia during the first 24 hours after ICU admission in patients after subarachnoid haemorrhage [31], and Young et al. similarly reported no association between worst $\mathrm{PaO}_{2}$ in the first 24 hours after ICU admission and mortality in patients with acute ischaemic stroke [36]. However, other observational studies have reported detrimental effects on short and longer term outcomes in different groups of stroke patients [28, 30]. A study randomizing patients to room air or supplemental oxygen administered at $30-45 \mathrm{~L} / \mathrm{min}$ for 8 hours was terminated early because of more deaths in the oxygen group (NCT00414726). In a pilot study comparing oxygen supplementation for $72 \mathrm{~h}$ via nasal cannulae with room air in 289 patients with acute stroke, there was a small improvement in neurological recovery at one week [37], but there were no significant differences between the groups at 6 months [38], findings supported by the larger Stroke Oxygen Study in more than 8000 patients [39].

2.3. In Sepsis and Septic Shock. The use of hyperoxia in patients with sepsis is also controversial [40]. Sepsis is already associated with increased formation of ROS, believed to play a role in the tissue damage and organ dysfunction seen during sepsis. Hyperoxaemia is known to stimulate release of ROS and could therefore further worsen organ function in these patients. In a rat caecal ligation and puncture model, hyperoxia was associated with increased inflammatory cytokine release and organ dysfunction compared to normoxia [41].
However, in other animal models of sepsis, hyperoxia has been associated with improved haemodynamics and antiinflammatory effects [42, 43]. And in a sheep model of sepsis, we showed that hyperoxia was associated with better haemodynamics and organ function compared to normoxia (unpublished data). In experimental human endotoxaemia, hyperoxia had no effect on levels of inflammatory mediators [44], and in a small observational study of patients with suspected sepsis in the emergency department, there were no significant differences in mortality rates between hyperoxic and normoxic patients [32]. A clinical trial in patients with sepsis randomized to hyperoxia or normoxia and hypertonic or isotonic saline in a $2 \times 2$ factorial design was stopped prematurely because of increased mortality rates in the hyperoxia and hypertonic saline arms (NCT01722422). Two randomized studies, one comparing supplemental oxygen titrated to different $\mathrm{PaO}_{2}$ targets $(105-135 \mathrm{mmHg}$ versus 60$90 \mathrm{mmHg}, \mathrm{O}_{2}$-ICU study, NCT02321072) and one comparing supplemental oxygen at $15 \mathrm{~L} / \mathrm{min}$ to no supplemental oxygen (NCT02378545), are currently ongoing and should provide final answers as to whether or not patients with sepsis may benefit from hyperoxia.

2.4. In Mixed ICU Patients. Use of liberal oxygen therapy is frequent in critically ill patients [45] and severe hyperoxaemia $\left(\mathrm{PaO}_{2}>200 \mathrm{mmHg}\right)$ is associated with higher mortality rates [35]. Interestingly, in three ICUs in the Netherlands, more than $70 \%$ of ICU patients had $\mathrm{PaO}_{2}$ levels that were higher than the upper limits identified by the ICU clinicians treating them [46]. Several studies have now compared so-called conservative oxygen strategies targeting lower $\mathrm{PaO}_{2}$ or $\mathrm{SpO}_{2}$ values with conventional oxygen administration. Panwar et al. compared target $\mathrm{SpO}_{2}$ values of $88-92 \%$ and $\geq 96 \%$ in 103 ICU patients and reported no significant differences between the groups in terms of organ function or ICU and 90-day mortality [33]. In the Oxygen-ICU study, which was terminated early, 434 patients were randomized to receive supplemental oxygen to maintain $\mathrm{PaO}_{2}$ at $70-100 \mathrm{mmHg}$ $\left(\mathrm{SpO}_{2}\right.$ 94-98\%) or to be managed conventionally allowing $\mathrm{PaO}_{2}$ to reach $150 \mathrm{mmHg}\left(\mathrm{SpO}_{2}\right.$ 97-100\%) [34]. Patients in the conservative group had lower ICU mortality than those in the conventional group (relative risk 0.57 [95\% CI 0.37-0.9]; $p=0.01)$.

\section{Conclusions}

For many years, the known risks of hypoxia and less known adverse effects of hyperoxia have led to many patients receiving liberal oxygenation to avoid hypoxaemia at all costs. Although good quality data remain limited, results from the latest clinical studies seem to suggest that hyperoxaemia may be associated with worse outcomes in some critically ill patients (Table 1). The trend is therefore moving towards a more conservative approach to oxygenation aimed at maintaining $\mathrm{SpO}_{2}$ targets at 95-97\%, although the optimal $\mathrm{PaO}_{2}$ level has not yet been defined and will likely change during the course of a patient's illness. Indeed, there may be a time window during which patients may benefit from higher oxygen levels [47]. Further well-designed randomized 
controlled trials in carefully selected groups of patients may help provide some definitive answers to these questions. As with other areas of intensive care management, oxygen therapy should be individualized. Patients who are hypoxaemic clearly need to receive supplemental oxygen, but ongoing requirements need to be reassessed on a regular basis to limit any risks associated with hyperoxia.

\section{Competing Interests}

The authors declare that there are no competing interests regarding the publication of this paper.

\section{References}

[1] J. E. Heffner, “The story of oxygen," Respiratory Care, vol. 58, no. 1, pp. 18-31, 2013.

[2] J. W. Severinghaus, "Priestley, the furious free thinker of the enlightenment, and Scheele, the taciturn apothecary of Uppsala," Acta Anaesthesiologica Scandinavica, vol. 46, no. 1, pp. 2-9, 2002.

[3] R. L. Parke, G. M. Eastwood, and S. P. McGuinness, "Oxygen therapy in non-intubated adult intensive care patients: a point prevalence study," Critical Care and Resuscitation, vol. 15, no. 4, pp. 287-293, 2013.

[4] E. de Jonge, L. Peelen, P. J. Keijzers et al., "Association between administered oxygen, arterial partial oxygen pressure and mortality in mechanically ventilated intensive care unit patients," Critical Care, vol. 12, no. 6, article R156, 2008.

[5] C. Brueckl, S. Kaestle, A. Kerem et al., "Hyperoxia-induced reactive oxygen species formation in pulmonary capillary endothelial cells in situ," American Journal of Respiratory Cell and Molecular Biology, vol. 34, no. 4, pp. 453-463, 2006.

[6] T. E. Zaher, E. J. Miller, D. M. P. Morrow, M. Javdan, and L. L. Mantell, "Hyperoxia-induced signal transduction pathways in pulmonary epithelial cells," Free Radical Biology and Medicine, vol. 42, no. 7, pp. 897-908, 2007.

[7] F. Sjöberg and M. Singer, "The medical use of oxygen: a time for critical reappraisal," Journal of Internal Medicine, vol. 274, no. 6, pp. 505-528, 2013.

[8] D. Orbegozo Cortés, F. Puflea, K. Donadello et al., "Normobaric hyperoxia alters the microcirculation in healthy volunteers," Microvascular Research, vol. 98, pp. 23-28, 2015.

[9] E. Calzia, P. Asfar, B. Hauser et al., "Hyperoxia may be beneficial," Critical Care Medicine, vol. 38, no. 10, pp. S559-S568, 2010.

[10] A. M. Dell'Anna, I. Lamanna, J.-L. Vincent, and F. S. Taccone, "How much oxygen in adult cardiac arrest?" Critical Care, vol. 18, no. 5, article 555, 2014.

[11] J. H. Kilgannon, A. E. Jones, N. I. Shapiro et al., "Association between arterial hyperoxia following resuscitation from cardiac arrest and in-hospital mortality," JAMA-Journal of the American Medical Association, vol. 303, no. 21, pp. 2165-2171, 2010.

[12] J. Elmer, M. Scutella, R. Pullalarevu et al., "The association between hyperoxia and patient outcomes after cardiac arrest: analysis of a high-resolution database," Intensive Care Medicine, vol. 41, no. 1, pp. 49-57, 2015.

[13] G. M. Eastwood, A. Tanaka, E. D. V. Espinoza et al., "Conservative oxygen therapy in mechanically ventilated patients following cardiac arrest: a retrospective nested cohort study," Resuscitation, vol. 101, pp. 108-114, 2016.
[14] D. Stub, K. Smith, S. Bernard et al., "Air versus oxygen in STsegment-elevation myocardial infarction," Circulation, vol. 131, no. 24, pp. 2143-2150, 2015.

[15] R. Hofmann, S. K. James, L. Svensson et al., "DETermination of the role of OXygen in suspected Acute Myocardial Infarction trial," American Heart Journal, vol. 167, no. 3, pp. 322-328, 2014.

[16] F. Xu, P. Liu, J. M. Pascual, G. Xiao, and H. Lu, "Effect of hypoxia and hyperoxia on cerebral blood flow, blood oxygenation, and oxidative metabolism," Journal of Cerebral Blood Flow and Metabolism, vol. 32, no. 10, pp. 1909-1918, 2012.

[17] H. Quintard, C. Patet, T. Suys, P. Marques-Vidal, and M. Oddo, "Normobaric hyperoxia is associated with increased cerebral excitotoxicity after severe traumatic brain injury," Neurocritical Care, vol. 22, no. 2, pp. 243-250, 2015.

[18] D. P. Davis, W. Meade Jr., M. J. Sise et al., "Both hypoxemia and extreme hyperoxemia may be detrimental in patients with severe traumatic brain injury," Journal of Neurotrauma, vol. 26, no. 12, pp. 2217-2223, 2009.

[19] M. Brenner, D. Stein, P. Hu, J. Kufera, M. Wooford, and T. Scalea, "Association between early hyperoxia and worse outcomes after traumatic brain injury," Archives of Surgery, vol. 147, no. 11, pp. 1042-1046, 2012.

[20] R. Raj, S. Bendel, M. Reinikainen et al., "Hyperoxemia and longterm outcome after traumatic brain injury," Critical Care, vol. 17, no. 4, article no. R177, 2013.

[21] A. Taher, Z. Pilehvari, J. Poorolajal, and M. Aghajanloo, "Effects of normobaric hyperoxia in traumatic brain injury: a randomized controlled clinical trial," Trauma Monthly, vol. 21, no. 1, Article ID e26772, 2016.

[22] A. Vilalta, J. Sahuquillo, M.-A. Merino et al., "Normobaric hyperoxia in traumatic brain injury: does brain metabolic state influence the response to hyperoxic challenge?" Journal of Neurotrauma, vol. 28, no. 7, pp. 1139-1148, 2011.

[23] R. Bellomo, M. Bailey, G. M. Eastwood et al., "Arterial hyperoxia and in-hospital mortality after resuscitation from cardiac arrest," Critical Care, vol. 15, no. 2, article no. R90, 2011.

[24] J. H. Kilgannon, A. E. Jones, J. E. Parrillo et al., "Relationship between supranormal oxygen tension and outcome after resuscitation from cardiac arrest," Circulation, vol. 123, no. 23, pp. 2717-2722, 2011.

[25] A. M. Ranchord, R. Argyle, R. Beynon et al., "High-concentration versus titrated oxygen therapy in ST-elevation myocardial infarction: a pilot randomized controlled trial," American Heart Journal, vol. 163, no. 2, pp. 168-175, 2012.

[26] D. R. Janz, R. D. Hollenbeck, J. S. Pollock, J. A. McPherson, and T. W. Rice, "Hyperoxia is associated with increased mortality in patients treated with mild therapeutic hypothermia after sudden cardiac arrest," Critical Care Medicine, vol. 40, no. 12, pp. 3135-3139, 2012.

[27] B. K. Lee, K. W. Jeung, H. Y. Lee et al., "Association between mean arterial blood gas tension and outcome in cardiac arrest patients treated with therapeutic hypothermia," American Journal of Emergency Medicine, vol. 32, no. 1, pp. 55-60, 2014.

[28] F. Rincon, J. Kang, M. Maltenfort et al., "Association between hyperoxia and mortality after stroke: a multicenter cohort study," Critical Care Medicine, vol. 42, no. 2, pp. 387-396, 2014.

[29] F. Rincon, J. Kang, M. Vibbert, J. Urtecho, M. K. Athar, and J. Jallo, "Significance of arterial hyperoxia and relationship with case fatality in traumatic brain injury: a multicentre cohort study," Journal of Neurology, Neurosurgery and Psychiatry, vol. 85, no. 7, pp. 799-805, 2014. 
[30] S.-B. Jeon, H. A. Choi, N. Badjatia et al., "Hyperoxia may be related to delayed cerebral ischemia and poor outcome after subarachnoid haemorrhage," Journal of Neurology, Neurosurgery and Psychiatry, vol. 85, pp. 1301-1307, 2014.

[31] M. Lang, R. Raj, M. B. Skrifvars et al., "Early moderate hyperoxemia does not predict outcome after aneurysmal subarachnoid hemorrhage," Neurosurgery, vol. 78, no. 4, pp. 540-545, 2016.

[32] R. Stolmeijer, J. C. Ter Maaten, J. G. Zijlstra, and J. J. M. Ligtenberg, "Oxygen therapy for sepsis patients in the emergency department: a little less?" European Journal of Emergency Medicine, vol. 21, no. 3, pp. 233-235, 2014.

[33] R. Panwar, M. Hardie, R. Bellomo et al., "Conservative versus liberal oxygenation targets for mechanically ventilated patients. A pilot multicenter randomized controlled trial," American Journal of Respiratory and Critical Care Medicine, vol. 193, no. 1, pp. 43-51, 2016.

[34] M. Girardis, S. Busani, E. Damiani et al., "Effect of conservative vs conventional oxygen therapy on mortality among patients in an intensive care unit: the Oxygen-ICU randomized clinical trial," The Journal of the American Medical Association, vol. 316, no. 15 , pp. 1583-1589, 2016.

[35] H. J. Helmerhorst, D. L. Arts, M. J. Schultz et al., "Metrics of arterial hyperoxia and associated outcomes in critical care," Critical Care Medicine, vol. 45, no. 2, pp. 187-195, 2017.

[36] P. Young, R. Beasley, M. Bailey et al., "The association between early arterial oxygenation and mortality in ventilated patients with acute ischaemic stroke," Critical Care and Resuscitation, vol. 14, no. 1, pp. 14-19, 2012.

[37] C. Roffe, K. Ali, A. Warusevitane et al., "The SOS pilot study: a RCT of routine oxygen supplementation early after acute stroke-effect on recovery of neurological function at one week," PLoS ONE, vol. 6, no. 5, Article ID e19113, 2011.

[38] K. Ali, A. Warusevitane, F. Lally et al., "The stroke oxygen pilot study: a randomized controlled trial of the effects of routine oxygen supplementation early after acute stroke-effect on key outcomes at six months," PLoS ONE, vol. 8, no. 6, Article ID e59274, 2013.

[39] S. Hafner, F. Beloncle, A. Koch, P. Radermacher, and P. Asfar, "Hyperoxia in intensive care, emergency, and peri-operative medicine: Dr. Jekyll or Mr. Hyde? A 2015 update," Annals of Intensive Care, vol. 5, no. 1, article 42, pp. 1-14, 2015.

[40] P. Asfar, E. Calzia, M. Huber-Lang, A. Ignatius, and P. Radermacher, "Hyperoxia during septic Shock-Dr. Jekyll or Mr. Hyde?" Shock, vol. 37, no. 1, pp. 122-123, 2012.

[41] R. Rodríguez-González, J. L. Martín-Barrasa, Á. Ramos-Nuez et al., "Multiple system organ response induced by Hyperoxia in a clinically relevant animal model of sepsis," Shock, vol. 42, no. 2, pp. 148-153, 2014.

[42] B. Hauser, E. Barth, G. Bassi et al., "Hemodynamic, metabolic, and organ function effects of pure oxygen ventilation during established fecal peritonitis-induced septic shock," Critical Care Medicine, vol. 37, no. 8, pp. 2465-2469, 2009.

[43] D. Waisman, V. Brod, M. A. Rahat et al., "Dose-related effects of hyperoxia on the lung inflammatory response in septic rats," Shock, vol. 37, no. 1, pp. 95-102, 2012.

[44] D. Kiers, J. Gerretsen, E. Janssen et al., "Short-term hyperoxia does not exert immunologic effects during experimental murine and human endotoxemia," Scientific Reports, vol. 5, article 17441, 2015.

[45] S. Suzuki, G. M. Eastwood, L. Peck, N. J. Glassford, and R. Bellomo, "Current oxygen management in mechanically ventilated patients: a prospective observational cohort study," Journal of Critical Care, vol. 28, no. 5, pp. 647-654, 2013.

[46] H. J. Helmerhorst, M. J. Schultz, P. H. van der Voort et al., "Selfreported attitudes versus actual practice of oxygen therapy by ICU physicians and nurses," Annals of Intensive Care, vol. 4, article 23, 2014.

[47] N. Ridler, J. Plumb, and M. Grocott, "Oxygen therapy in critical illness: friend or foe? A review of oxygen therapy in selected acute illnesses," Journal of the Intensive Care Society, vol. 15, no. 3, pp. 190-198, 2014. 


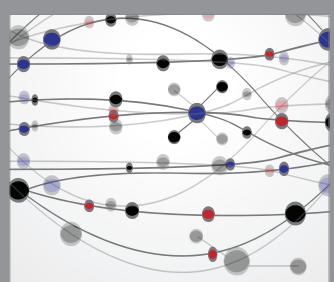

The Scientific World Journal
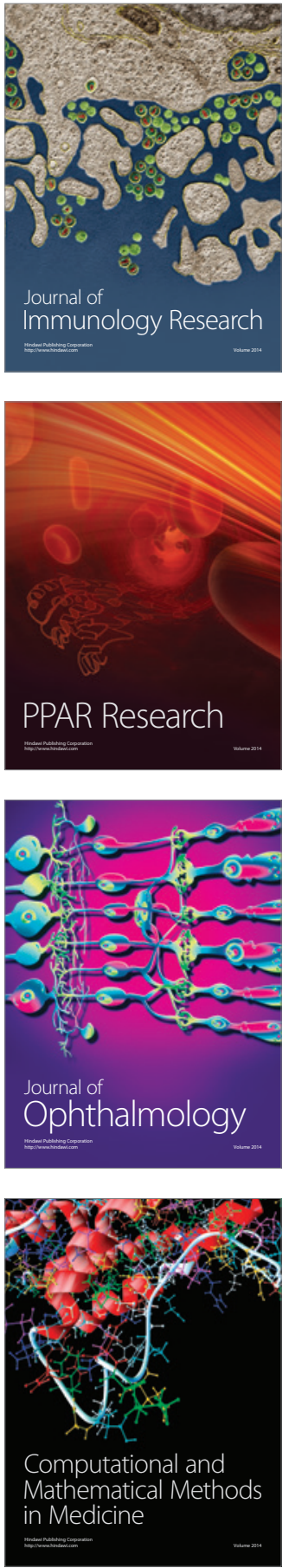

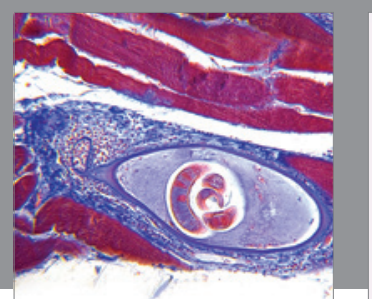

Gastroenterology Research and Practice
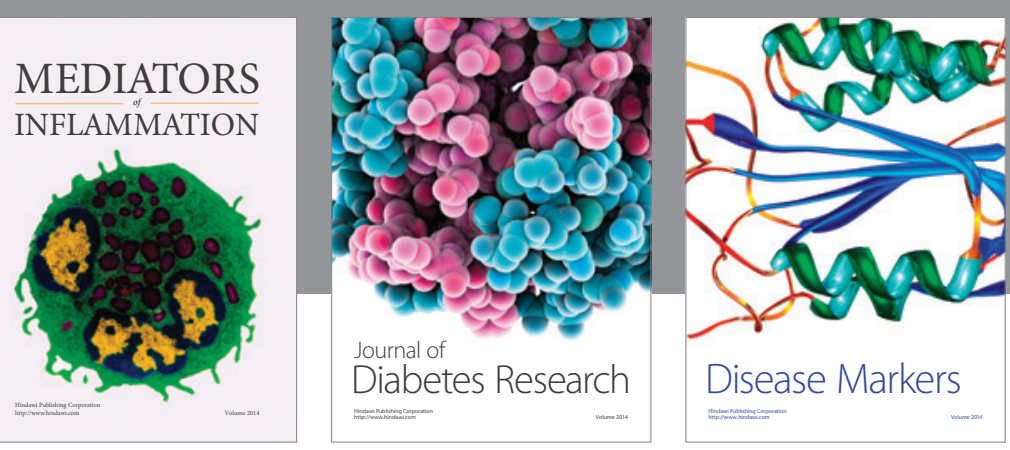

Disease Markers

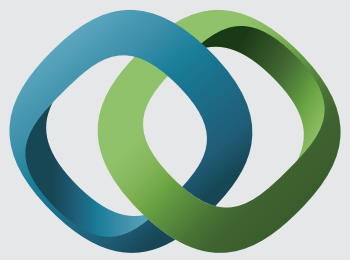

\section{Hindawi}

Submit your manuscripts at

https://www.hindawi.com
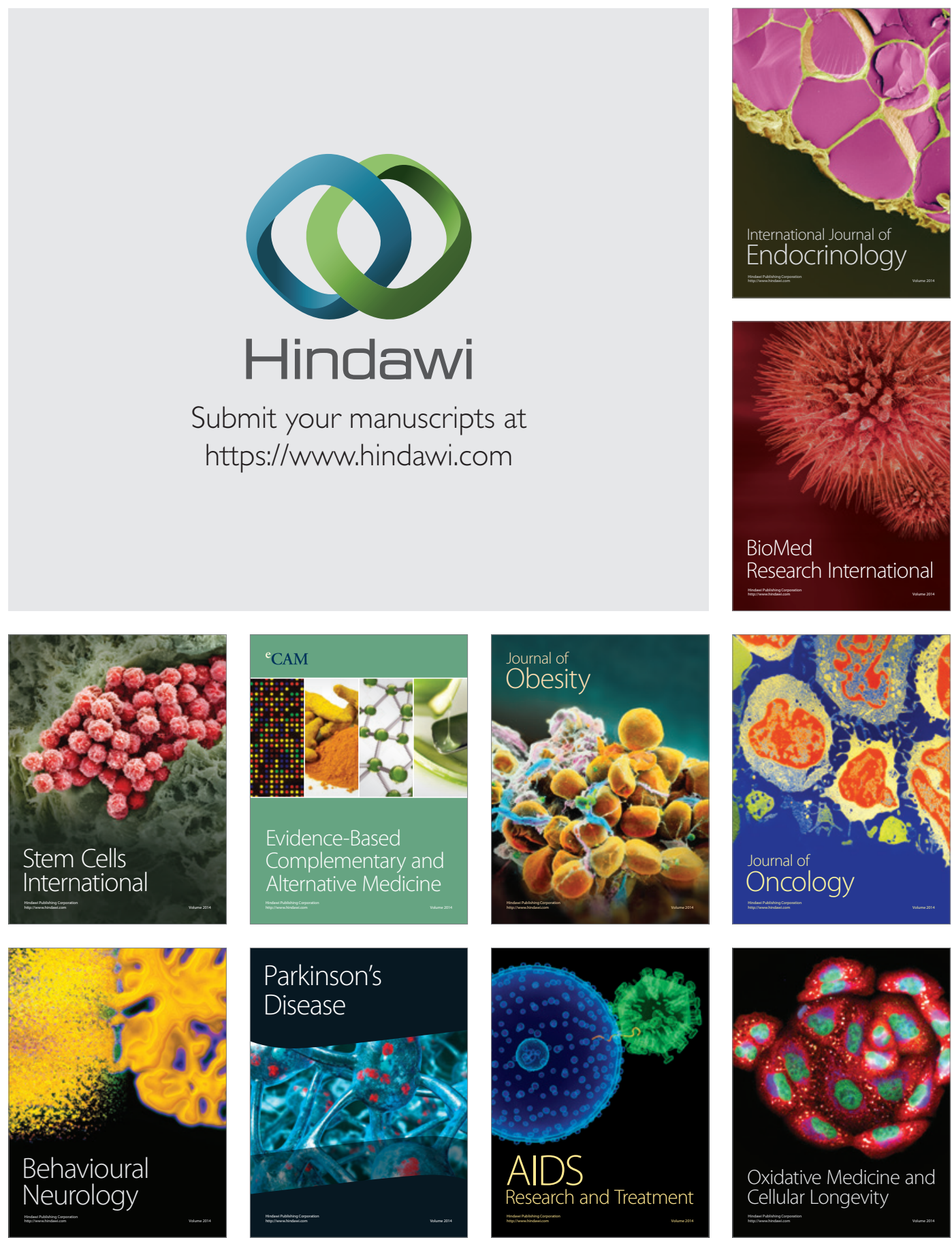